OPEN ACCESS

Edited by:

Massimiliano Caprio,

Università telematica San

Raffaele, Italy

Reviewed by:

Marco Infante,

University of Miami, United States

Valeria Guglielmi,

University of Rome Tor Vergata, Italy

*Correspondence:

Masayuki Saito

saito@vetmed.hokudai.ac.jp

Specialty section: This article was submitted to

Obesity,

a section of the journal

Frontiers in Endocrinology

Received: 10 February 2020

Accepted: 27 March 2020

Published: 21 April 2020

Citation:

Saito M, Matsushita M, Yoneshiro T and Okamatsu-Ogura Y (2020) Brown

Adipose Tissue, Diet-Induced

Thermogenesis, and Thermogenic Food Ingredients: From Mice to Men.

Front. Endocrinol. 11:222.

doi: $10.3389 /$ fendo.2020.00222

\section{Brown Adipose Tissue, Diet-Induced Thermogenesis, and Thermogenic Food Ingredients: From Mice to Men}

\author{
Masayuki Saito $^{1 *}$, Mami Matsushita ${ }^{2}$, Takeshi Yoneshiro ${ }^{3}$ and Yuko Okamatsu-Ogura ${ }^{1}$ \\ ${ }^{1}$ Faculty of Veterinary Medicine, Hokkaido University, Sapporo, Japan, ${ }^{2}$ Department of Nutrition, Tenshi College, Sapporo, \\ Japan, ${ }^{3}$ Division of Metabolic Medicine, Research Center for Advanced Science and Technology, The University of Tokyo, \\ Tokyo, Japan
}

Since the recent rediscovery of brown adipose tissue (BAT) in adult humans, this thermogenic tissue has been attracting increasing interest. The inverse relationship between BAT activity and body fatness suggests that BAT, because of its energy dissipating activity, is protective against body fat accumulation. Cold exposure activates and recruits BAT, resulting in increased energy expenditure and decreased body fatness. The stimulatory effects of cold exposure are mediated through transient receptor potential (TRP) channels and the sympathetic nervous system (SNS). Most TRP members also function as chemesthetic receptors for various food ingredients, and indeed, agonists of TRP vanilloid 1 such as capsaicin and its analog capsinoids mimic the effects of cold exposure to decrease body fatness through the activation and recruitment of BAT. The antiobesity effect of other food ingredients including tea catechins may be attributable, at least in part, to the activation of the TRP-SNS-BAT axis. BAT is also involved in the facultative thermogenesis induced by meal intake, referred to as diet-induced thermogenesis (DIT), which is a significant component of the total energy expenditure in our daily lives. Emerging evidence suggests a crucial role for the SNS in BAT-associated DIT, particularly during the early phase, but several gut-derived humoral factors may also participate in meal-induced BAT activation. One intriguing factor is bile acids, which activate BAT directly through Takeda G-protein receptor 5 (TGR5) in brown adipocytes. Given the apparent beneficial effects of some TRP agonists and bile acids on whole-body substrate and energy metabolism, the TRP/TGR5-BAT axis represents a promising target for combating obesity and related metabolic disorders in humans.

Keywords: bile acids, brown adipose tissue, diet-induced thermogenesis, food ingredients, gut hormone, obesity, sympathetic nervous system, transient receptor potential channels

\section{INTRODUCTION}

Brown adipose tissue (BAT) has long been recognized as the major site of non-shivering thermogenesis (NST) during cold exposure [cold-induced thermogenesis (CIT)] and arousal from hibernation in small rodents (1). Since the rediscovery of metabolically active BAT using fluorodeoxyglucose (FDG)-positron emission tomography (PET) and computed tomography (CT) in adult humans (2-5), subsequent experimental and clinical studies have dramatically increased our knowledge about the pathophysiological roles of BAT in the regulation of energy balance 
and body fatness $(6,7)$. Human BAT, as in the case of rodent BAT, is activated by acute cold exposure $(2,5)$ or administration of $\beta$-adrenergic receptor ( $\beta A R)$ agonists (8), and contributes to increasing whole-body energy expenditure (EE) and fatty acid oxidation (9-12). The activity and prevalence of BAT substantially decrease in older and obese populations $(2,3,13-16)$, and this age-related decline in BAT activity is closely associated with visceral fat accumulation (17). Prolonged exposure to cold recruits BAT, increases EE, and decreases body fat content (18-20). In addition, cold exposure improves glucose metabolism and insulin sensitivity (21-24). Thus, BAT could be a promising target to boost whole-body EE and prevent obesity and related metabolic disorders in humans (25-30).

Although cold exposure is undoubtedly the most physiological and effective regimen to activate and recruit BAT, it would be difficult and uncomfortable to increase human exposure to cold temperatures under well-controlled conditions with the presence of clothing and heating systems. Moreover, chronic cold exposure increases blood pressure (8) and may induce atherosclerosis (31). Thermogenesis observed after food intake [diet-induced thermogenesis (DIT)] is another component of NST. Although the involvement of BAT in DIT has been demonstrated in small rodents, only limited information is currently available in humans. The aim of this review article is to summarize and discuss the evidence for a role of BAT in DIT and thermogenesis induced by certain food ingredients in humans, considering that DIT is a significant component of whole-body EE in our usual daily life.

\section{COLD-INDUCED BAT THERMOGENESIS}

Although the mechanism of BAT-dependent CIT has mostly been investigated in small rodents, essentially the same mechanism is believed to work in humans. When animals are exposed to cold temperatures, cold is perceived by temperature sensors, transient receptor potential (TRP) channels, which are membrane proteins that transmit information about changes in the environment such as temperature, touch, pain, osmolarity, and naturally occurring substances (32). Cold-activated TRP on sensory neurons on the body surface transmit information to the brain and increase the activity of sympathetic nerves entering BAT (33). Noradrenaline (NA) released from sympathetic nerve endings stimulates brown adipocytes via the $\beta A R$ and triggers cyclic adenosine monophosphate (cAMP)-activated intracellular events including hydrolysis of triglyceride, oxidation of resulting fatty acids, and activation of uncoupling protein 1 (UCP1), a key

\footnotetext{
Abbreviations: $\beta A R, \beta$-adrenergic receptor; BA, bile acids; BAT, brown adipose tissue; CCK, cholecystokinin; CIT, cold-induced thermogenesis; COMT, catechol-O-methyl transferase; CT, computed tomography; DIT, diet-induced thermogenesis; EE, energy expenditure; DHA, docosahexaenoic acid; EPA, eicosapentaenoic acid; FDG, fluorodeoxyglucose; GLP-1, glucagon-like peptide1; GP, Grains of Paradise; NA, noradrenaline; NST, nonshivering metabolic thermogenesis; PET, positron emission tomography; SCTR, secretin receptor; SNS, sympathetic nervous system; TGR5, G-protein-coupled bile acid-activated receptor; TRP, transient receptor potential channel; TRPA1, TRP ankyrin subfamily member 1; TRPM8, TRP metastatin 8; TRPV1, TRP vanilloid 1; UCP1, uncoupling protein 1 .
}

mitochondrial molecule for BAT thermogenesis. Sympathetic activation also results in increased fat mobilization in white adipose tissue, and released fatty acids are used in peripheral tissues including BAT. Although the principal substrate for BAT thermogenesis is fatty acids, glucose utilization is also enhanced in parallel with UCP1 activation, probably for a sufficient supply of oxaloacetate to enable the rapid oxidation of fatty acids and acetyl coenzyme A (CoA), and also for recovery of cellular adenosine triphosphate (ATP) levels by activating anaerobic glycolysis (34). Thus, UCP1-dependent glucose utilization could be a metabolic index of BAT thermogenesis, and has been applied in FDG-PET for assessing human BAT.

When animals are exposed to cold temperatures for a long time, they adapt to their surroundings by increasing the number of brown adipocytes and the amount of UCP1 through the proliferation of interstitial preadipocytes and matured adipocytes $(35,36)$. In addition to BAT hyperplasia, prolonged cold exposure gives rise to an apparent induction of UCP1-positive adipocytes in white adipose tissue. This type of adipocytes, termed "beige" or "brite" cells, is developmentally distinct from "classical" brown adipocytes, which derive from Myf5-positive myoblastic cells $(6,37)$. Thus, chronic cold exposure results in increased EE through the persistent activation and recruitment of classical brown adipocytes and beige cells, and the consequent "browning" of white adipose tissue and body fat reduction. As the FDG-PET/ CT-detected and UCP1-positive human adipose depot consists of a mixture of brown and beige adipocytes (38-41), hereafter we shall refer to it collectively as BAT.

\section{DIET-INDUCED ACTIVATION OF BAT}

EE above the basal metabolic rate in response to meal intake is referred to as the "specific dynamic action of food," "thermic effects of food," or "DIT." The term DIT has often been used to describe the adaptive increase in EE observed after longterm overfeeding, which is also known as "luxury consumption" or "luxosconsumption." Since the publication of the report of Rothwell and Stock (42) in 1979, it has been demonstrated in small rodents that daily spontaneous feeding of high-calorie diets such as high-fat and cafeteria diets resulted in a lower energy efficiency with less weight gained than expected on the basis of on caloric intake, in parallel with an increased BAT activity and EE (43). The adaptive changes in response to overfeeding are not observed in animals without UCP1 (44). Thus, the role of BAT in adaptive increase in EE and maintaining energy balance seems to have been accepted, albeit not widely supported (45).

Thermogenesis after a single meal is expressed as the percentage of the energy content of the food ingested ( $\sim 10 \%$ for standard meals in humans). This is usually divided into two components: obligatory and facultative thermogenesis. Obligatory thermogenesis refers to the obligatory response including digestion, absorption, and storage of ingested nutrients, whereas facultative thermogenesis refers to the additional responses to obligatory thermogenesis and may be closely related to the adaptive increase in EE. In this work, we tentatively refer to facultative thermogenesis in response to single 
meals as DIT and discuss its mechanisms and pathophysiological relevance in the context with BAT.

Activation of BAT after a single meal was suggested in the 1980 s by Glick et al. (46), who reported increased respiration rate of BAT in $2 \mathrm{~h}$ after food intake in rats. They also demonstrated a meal-induced increase in guanosine $5^{\prime}$-diphosphate (GDP) binding to mitochondria isolated from BAT, which was used as an index of UCP1 activation (47). Our team (48) found mealinduced metabolic activation of BAT in rats-that is, in $30 \mathrm{~min}$ after oral intake of a liquid meal, glucose utilization and fatty acid synthesis were increased in intact BAT, but to a much lower extent in surgically denervated BAT. The critical role of UCP1 in DIT was proved by simultaneous 24 -h recording of food intake and oxygen consumption in UCP1-deficient mice maintained at a thermoneutral temperature of $30^{\circ} \mathrm{C}$-that is, whole-body oxygen consumption in UCP1-deficient mice was lower than that in wild-type mice, particularly during the eating period (44).

\section{DIET-INDUCED BAT THERMOGENESIS IN HUMANS}

In humans, the possible contribution of BAT thermogenesis to DIT and regulation of energy balance have been suggested by studies on single nucleotide polymorphism in some BAT-related genes. For example, Trp64Arg mutation in the $\beta 3$ adrenergic receptor $(\beta 3 A R)$ gene and $\mathrm{A} 3826 \mathrm{G}$ mutation in the UCP1 gene are associated with higher body fatness, lower metabolic rate, and smaller weight loss via treatment with low-calorie diets (49-52). Nagai et al. (53) examined the effects of A-3826G mutation in the UCP1 gene on DIT in boys, and found a reduced response $3 \mathrm{~h}$ after a high-fat meal in those carrying the $\mathrm{G}$ allele. They also found diminished CIT in the group with the GG allele compared with those carrying the AA + AG alleles (54).

Rediscovery of BAT in adult humans has prompted further studies to test whether BAT thermogenesis is activated after single meals. Vrieze et al. (55) measured BAT activity using FDG-PET/CT in healthy volunteers $90 \mathrm{~min}$ after meal intake, and unexpectedly found a reduction in FDG uptake into BAT compared with that after overnight fasting. Vosselman et al. (56) also reported that postprandial FDG uptake into BAT was much lower than cold-induced uptake, whereas whole-body EE was comparable. Although these results seem to be in conflict with the idea of postprandial activation of BAT thermogenesis, they can be explained by increased insulin-stimulated FDG uptake into skeletal muscle, which reduces FDG bioavailability for BAT, which in turn leads to underestimation of BAT activity. FDG uptake after a mild cold exposure is increased specifically in BAT, whereas that after food intake is increased in many insulinsensitive tissues such as skeletal muscle, brown and white adipose tissue, and heart (10). Thus, although FDG uptake into BAT can be used as an index of BAT activity under certain restricted conditions, it is not always associated with BAT thermogenesis.

This limitation of FDG-PET/CT is overcome by measuring oxygen uptake using ${ }^{15} \mathrm{O}\left[\mathrm{O}_{2}\right]$-PET and blood flow using ${ }^{15} \mathrm{O}\left[\mathrm{H}_{2} \mathrm{O}\right]-\mathrm{PET}$, which are more descriptive indicators of thermogenesis and mitochondrial substrate oxidation. In fact, acute cold exposure evoked a marked increase in oxygen consumption and blood flow in parallel with increased wholebody EE (57). Moreover, Din et al. (58) demonstrated that oxygen consumption and blood flow in BAT rose immediately after meal intake to an extent comparable to those observed after cold exposure. To confirm the role of BAT in DIT, we measured whole-body EE continuously for $24 \mathrm{~h}$ in healthy humans using a human calorimeter (59). When the participants were divided into high BAT and low BAT groups according to the result of FDG-PET/CT examination, there was no significant difference in body composition and resting EE between the two groups. However, EE after meals was significantly higher in the high BAT group ( $9.7 \%$ of the total energy intake) than in the low BAT group (6.5\%). Of note, the 24 -h respiratory quotient was also apparently lower in the high BAT group, implying higher fat oxidation. Higher postprandial whole-body EE and substrate oxidation were also confirmed in participants with higher BAT activities (57). All these results indicate that BAT contributes to DIT, at least in part, in humans. This may also be indirectly supported by the finding that BAT recruitment by prolonged cold exposure is accompanied by enhanced DIT (21).

\section{MECHANISMS OF DIT: THE SYMPATHETIC NERVOUS SYSTEM (SNS)}

Based on the principal role of the SNS- $\beta$ AR axis for CIT, it is conceivable that this axis is a key mechanism in dietinduced/postprandial BAT thermogenesis (Figure 1). In fact, in both experimental animals and humans, the plasma levels of NA and tissue NA turnover are low during fasting but increases immediately after food intake (60-63). Moreover, SNS activity in BAT estimated from tissue NA turnover is increased in mice chronically overfed with cafeteria and high-calorie diets $(64,65)$. Meanwhile, our team (48) found that in rats metabolic activation of BAT after intake of a liquid meal was diminished after surgical severing of sympathetic nerves entering BAT. These results are in line with the idea that diet-induced/postprandial BAT thermogenesis is mediated through sympathetic nerve activation. One interesting observation in our studies was that the mealinduced metabolic activation and NA turnover in BAT were reduced in rats given the same meal through a gastric tube. In the case of humans and dogs, LeBlanc et al. $(66,67)$ showed that responses in oxygen consumption, and plasma levels of NA and insulin shortly (1-2h) after food intake were substantially reduced when food was administered through a stomach tube. They also reported lowered postprandial thermogenesis with a non-palatable meal in comparison with a highly palatable meal, despite using the same composition and amount in both meals (68). These results suggest that food palatability and oropharyngeal taste sensation play a significant role in dietinduced sympathetic activation and BAT thermogenesis. This may be consistent with the observation that the cafeteria feeding regimen with palatable foods is most efficient in producing a concomitant voluntary hyperphagia, elevated SNS activity, and BAT hyperplasia, thereby resulting in "luxsusconsumption." 


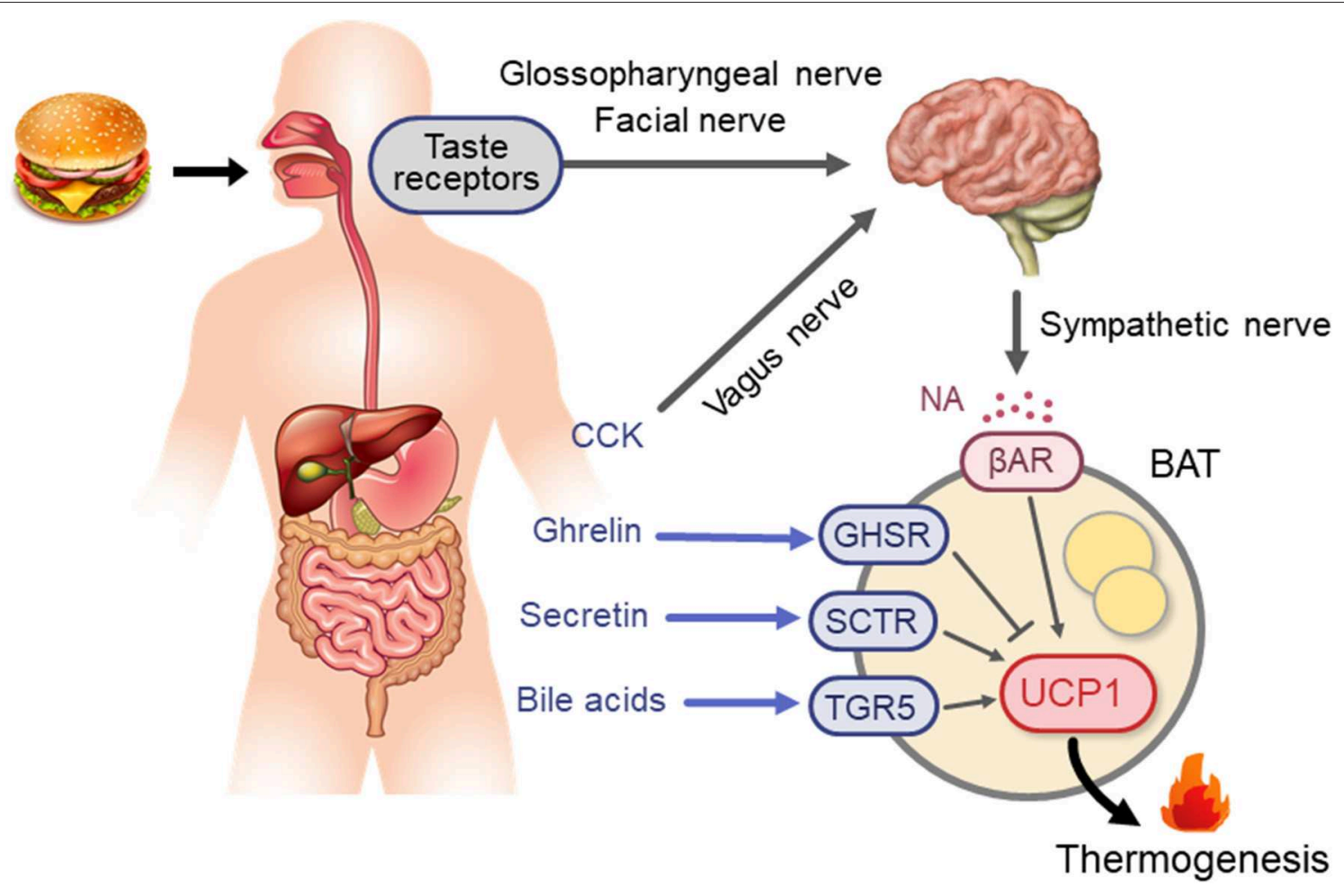

FIGURE 1 | Neural and endocrine mechanisms for BAT thermogenesis activated after meal intake. $\beta$ AR, $\beta$-adrenergic receptor; BA, bile acids; BAT, brown adipose tissue; CCK, cholecystokinin; GHSR, ghrelin receptor; NA, noradrenaline; SCTR, secretin receptor; TGR5, G-protein-coupled bile acid-activated receptor; UCP1, uncoupling protein 1.

Thus, the SNS-BAT axis may be crucial for DIT, particularly during the early phase, in the same way as for CIT; however, this implication still seems controversial in humans. Wijers et al. (69) reported considerable interindividual variations in thermogenic responses to 84-h intervention by overfeeding and mild cold exposure in 13 male individuals, but a high correlation between the responses to the two interventions, suggesting a common regulation mechanism shared in DIT and CIT. However, there have been reports of an apparent dissociation of DIT with CIT in cold-adapted humans. For example, Peterson et al. (70) demonstrated that daily exposure of healthy men to cold temperatures for 4 weeks resulted in a 2-fold increase in CIT, in parallel with increased SNS activity, whereas it did not change the thermic effect of food. Lee et al. (21) also reported a dissociation between the effects of prolonged cold exposure on DIT and CIT. Moreover, blockade of $\beta$ AR with propranolol was demonstrated to have only a small effect on the increase in whole-body EE after intake of carbohydrate-rich meals (71-73). All these results suggest that DIT in humans is regulated by some mechanisms different from, and/or in combination with, the SNS- $\beta A R$ axis.

\section{MECHANISMS OF DIT: GUT HORMONES AND BILE ACIDS}

One of the likely factors involved in DIT may be gut hormones. Li et al. (74) found abundant expression of the secretin receptor
(SCTR) in murine brown adipocytes, and demonstrated that secretin activates UCP1- and SCTR-dependent thermogenesis in vitro and in vivo. They also confirmed that the increment of plasma secretin levels induced by a single meal positively correlated with oxygen consumption and fatty acid uptake rates in BAT in humans. These observations collectively support the idea that meal-associated increase in circulating secretin activates BAT thermogenesis by binding to SCTR in brown adipocytes. Direct evidence for the thermogenic action of secretin on human BAT was obtained using FDG-PET/CT after secretin infusion, which significantly increased FDG uptake in supraclavicular BAT.

In addition to secretin, other gut hormones are also known to activate or suppress BAT thermogenesis in small rodents. Recently, Yamazaki et al. (75) reported that in rats, peripherally administered cholecystokinin (CCK) activates the SNS-BAT axis via the CCK receptor and vagal afferent nerves. Blouet and Shwartz (76) also demonstrated that in rats BAT thermogenesis induced by intraduodenal administration of lipids was abolished by administration of either the CCK receptor antagonist devazepide or the $\mathrm{N}$-methyl-D-aspartate receptor blocker MK801 directly into the caudomedial nucleus of the solitary tract. These results collectively indicate that CCK activates BAT thermogenesis via vagal afferent and sympathetic efferent nerves. In fact, Vijgen et al. (77) demonstrated that vagal afferents played a role in BAT thermogenesis in humans: vagus nerve 
stimulation significantly increases whole-body EE in parallel with BAT activity assessed by FDG-PET/CT.

CCK is an anorexigenic hormone secreted from the duodenum after food intake, whereas ghrelin is an orexigenic hormone and its secretion from the stomach is reduced after food intake. Lin et al. (78) reported that ghrelin decreases UCP1 expression in brown adipocytes, and that during aging, plasma ghrelin and ghrelin receptor expression in BAT increases whereas BAT thermogenesis declines. It is thus possible that reduced secretion of ghrelin, together with increased secretion of CCK and secretin, contributes to BAT activation in response to food intake. This may be supported by an association of BAT with systemic concentrations of some gut hormones including ghrelin in humans (79). Thus, there are multiple factors/mechanisms for diet-induced/postprandial BAT thermogenesis, their actions being synergistic or independent of each other. However, the precise nature of their roles in DIT and whole-body EE in humans remain largely unexplained to date.

Another humoral factor may be bile acids (BA), which are secreted into the intestinal lumen in response to meal intake, modified by gut flora, and mostly returned to the liver. During enterohepatic circulation, BA is partially transferred into general circulation, resulting in a rapid postprandial increase in its plasma concentration $(80,81)$. BA are now recognized as a metabolic regulator, affecting multiple functions, in addition to lipid-digestive functions, to regulate energy metabolism, as well as glucose and lipid metabolism, through the activation of nuclear farnesoid $\mathrm{X}$ receptor and the $\mathrm{G}$ protein-coupled membrane receptor TGR5 (Takeda G-protein receptor 5) (82). In connection with the thermogenic and antiobesity effects of BA, Watanabe et al. (83) demonstrated that in mice BA activates TGR5 in brown adipocytes, leading to activation of type 2 deiodinase and increased thermogenic activity. Similar direct stimulatory effects of BA chenodeoxycholic acid on BAT were reported in humans using brown adipocytes in vitro and using FDG-PET/CT in vivo (84). BA also stimulates intestinal Lcell TGR5 to secrete glucagon-like peptide-1 (GLP-1). Although GLP-1 is known as an incretin to stimulate insulin secretion, it activates BAT thermogenesis and induces beige fat development through the action on its receptor in the hypothalamus (85) and the AMPK-SIRT-1-PGC1- $\alpha$ (AMP-activated protein kinasesirtuin 1-peroxisome proliferator-activated receptor gamma coactivator 1-alpha) cell signaling pathway (86). Crucial roles of TGR5 were also demonstrated in browning of white adipose tissue under multiple environmental cues including cold exposure and prolonged high-fat diet feeding (87).

\section{BAT THERMOGENESIS AND DIETARY FAT}

Thermogenesis after a single meal is usually estimated to be $10 \%$ for standard meals; it varies depending on the composition of meals, being $\sim 3 \%$ for fat, $7 \%$ for carbohydrate, and $30 \%$ for protein. In contrast, sympathetic and BAT activation, and probably facultative thermogenesis (DIT), are low in animals fed on high-protein diets $(88,89)$. Accordingly, high-fat diets and/or cafeteria diets with high carbohydrate and fat contents have been widely used for activation and recruitment of BAT. In this context, what is interesting is that some types of dietary fat including fish oil help prevent cardiovascular and metabolic diseases, and visceral fat accumulation (90). Moreover, several studies conducted in human volunteers have reported that postprandial thermogenesis is greater after intake of a meal rich in polyunsaturated fatty acids compared to that rich in monosaturated and saturated fatty acids $(91,92)$. Earlier studies in rats have revealed that dietary fish oil and/or eicosapentaenoic acid (EPA) and docosahexaenoic acid (DHA) rich in fish oil enhance $\mathrm{EE}$ and prevent fat accumulation by inducing UCP1 in BAT $(93,94)$. Kim et al. (95) reported that UCP1 induction by dietary EPA and DHA is blocked by either subdiaphragmatic vagotomy or treatment with a $\beta A R$ blocker. They also demonstrated that the thermogenic and antiobesity effects of EPA and DHA are abolished in mice lacking TRP vanilloid 1 (TRPV1), a member of the TRP family activated by vanilloid compounds. Considering that EPA and DHA have agonistic activity on TRPV1, it is likely that these polyunsaturated fatty acids stimulate the vagus nerve through TRPV1 in the gut, thereby activating the SNS- $\beta$ AR axis and BAT thermogenesis (Figure 2).

In addition, direct action mechanisms of EPA in brown adipocytes have also been proposed. To cite an example, Kim et al. (96) reported that EPA is sensed by the membrane receptor free fatty acid receptor 4 in brown adipocytes, resulting in biogenesis of the microRNAs miR-30b and miR-378 and an increase of intracellular cAMP levels, both of which promote the transcriptional activation of brown adipogenesis, including UCP1 induction. The UCP1-inducing effects of EPA are also reported to be mediated via inhibition of production of w6-derived oxygenated metabolites, such as oxylipins, that can impair UCP1 activation and induction (97). Despite the abundance of evidence in rodents, however, the thermogenic effect of EPA and DHA and its relation to BAT in humans remain to be investigated. In this context, one interesting development is a recent report by Leiria et al. (98), who observed that administration of a $\beta 3 \mathrm{AR}$ agonist induces a rapid increase in the plasma levels of 12- hydroxyeicosapentaenoic acid (12-HEPE) and 14-hydroxydocosahesanoic acids (14-HDHA), lipoxygenase products of EPA and DHA, in parallel with the BAT activity assessed by FDG-PET/CT, in humans. They also demonstrated in mice that activated brown adipocytes released 12-HEPE to promote glucose uptake into skeletal muscle and adipose tissues. Thus, it seems possible that 12-HEPE is a BAT-derived factor that improves insulin sensitivity and glucose metabolism (21-24).

\section{BAT THERMOGENESIS INDUCED BY CAPSAICIN AND CAPSINOIDS}

BAT thermogenesis is also induced by various non-caloric food ingredients and natural substances. One example of such ingredients is capsaicin, the major pungent component of chili peppers, which happens to be a potent activator of TRPV1. Capsaicin is the most consumed spice in the world, and its health beneficial effects, including thermogenic and antiobesity activities, have been known for centuries (99-101). However, because of its strong pungency, not everyone can consume capsaicin in large quantities. Capsinoids (capsiate, 


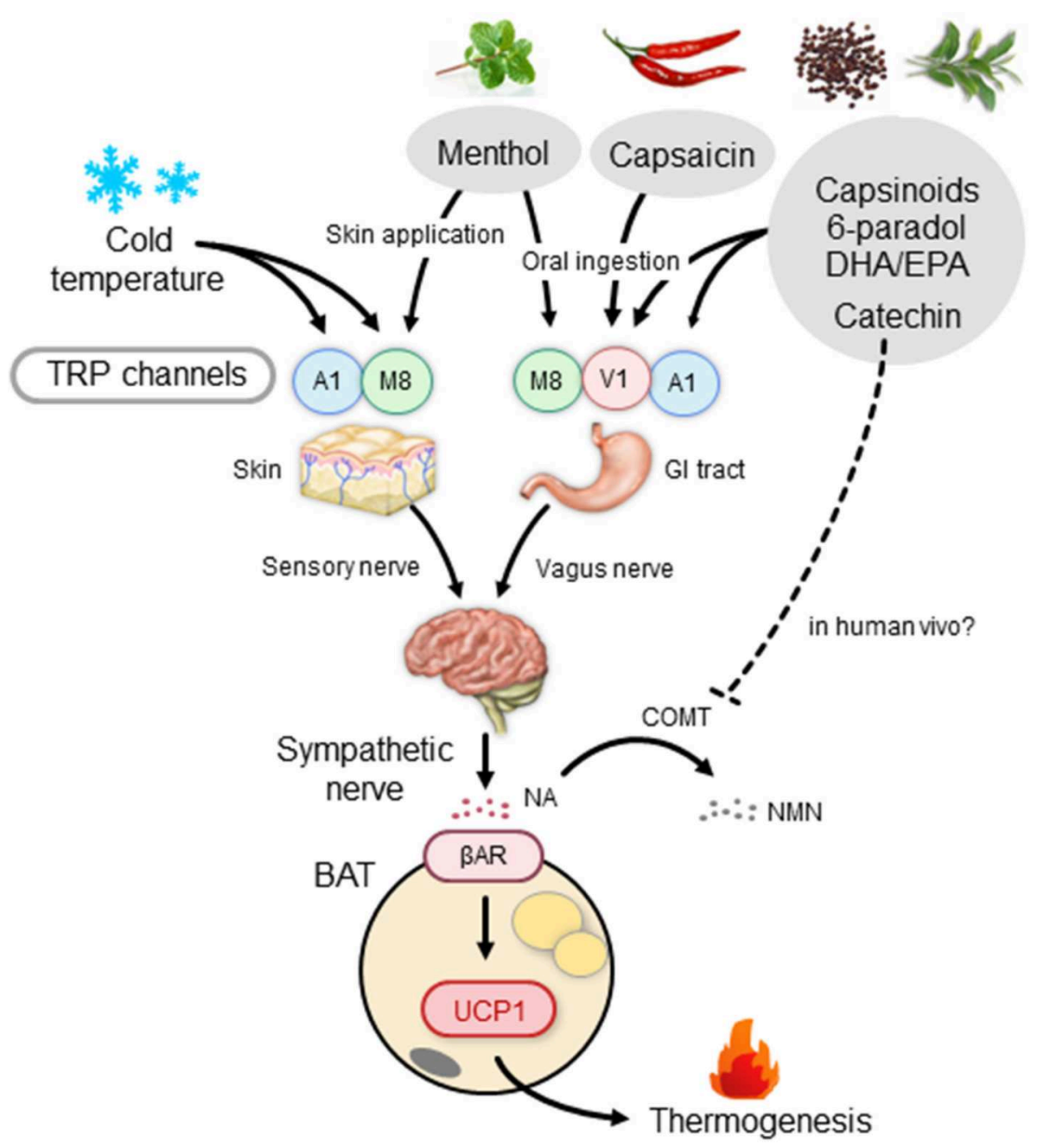

FIGURE 2 | BAT thermogenesis through the activation of the TRP-SNS axis by food ingredients. $\beta A R$, $\beta$-adrenergic receptor; BAT, brown adipose tissue; COMT, catechol-O-methyl transferase; DHA, docosahexaenoic acid; EPA, eicosapentaenoic acid; Gl tract, gastrointestinal tract; NA, noradrenaline; NMN, normetanephrine; SNS, sympathetic nervous system; TRP, transient receptor potential channel; A1, TRP ankyrin subfamily member 1; M8, TRP metastatin 8; V1, TRP vanilloid 1; UCP1, uncoupling protein 1.

dihydrocapsiate, and nordihydrocapsiate) are capsaicin-like compounds found in a non-pungent type of red pepper, " $\mathrm{CH}$ 19 Sweet" (102). Capsaicin and capsinoids bind to TRPV1 with comparable affinities; however, pungency is much less defined in capsinoids $(1 / 1,000)$. The low pungency exhibited by capsinoids may be attributable to the high lipophilicity of capsinoids, which render these molecules unable to access the termini of trigeminal nerves in the oral cavity, which is covered with epithelium (103).

Animal studies have demonstrated that oral administration of capsaicin and/or capsinoids can activate TRPV1 expressed in sensory nerves within the gastrointestinal tract and increase sympathetic nerve activity innervating BAT, inducing a rapid increase in BAT temperature, increasing whole-body EE, and decreasing body fat (104-106). These responses are blunted by the administration of $\beta$-adrenergic blockers (106) or through the denervation of vagal afferents and extrinsic nerves connected to the jejunum $(104,105)$. It was also reported that the thermogenic and fat-reducing effects of capsinoids are diminished in mice lacking either TRPV1 or UCP1 (105, 107, 108). Taken together, oral administration of either pungent capsaicin or non-pungent capsinoids increases whole-body EE and prevents obesity through the activation of the TRPV1-SNS-BAT axis in small rodents. It is possible that capsaicin also acts directly on TRPV1 expressed in BAT (109). By contrast, the direct action of capsinoids on TRPV1 in brown adipocytes is unlikely because orally ingested capsinoids are rapidly hydrolyzed in the small intestine and are usually undetectable in general circulation (110).

In humans, our team (111) found that a single oral ingestion of capsinoids increases EE in individuals with metabolically active BAT, but not in those without it. These findings indicate that the thermogenic effects of capsinoids are dependent on the presence of BAT-implying that capsinoids activate BAT and thereby increase EE. Furthermore, daily ingestion of capsinoids 
for 6 weeks augments CIT in individuals with low BAT activities (18). Because interindividual (26) and intraindividual variations of CIT (112) are significantly related to BAT activity assessed by FDG-PET/CT, the capsinoid-induced increase in CIT reflects the recruitment of BAT. This was directly confirmed by using FDG-PET/CT $(113,114)$ and also through near-infrared timeresolved spectroscopy (NIRTRS) (114), a novel method for evaluating BAT density in a specific region of interest (115). Thus, capsinoids have the potential to activate and recruit human BAT, thereby contributing to their antiobesity effect. Indeed, after a 12-week oral ingestion of capsinoids, a slight but significant reduction of abdominal fat was observed in a group of obese individuals (116). Notably, the fat-reducing effect of capsinoids is attenuated in individuals who carry a mutated (Val585Ile) TRPV1 (116), consistent with the crucial role of TRPV1 in mice. As single and daily oral ingestions of capsinoids at doses of 30 (110) and 6-9 mg/day for 6-12 weeks $(18,114$, 116), respectively, produced no serious adverse events, dietary supplementation with capsinoids appears to be safe and feasible for combating obesity.

Although the effects of capsinoids are similar to those of cold exposure, TRPV1 is not a cold sensor, but rather a sensor of noxious hot temperatures and low $\mathrm{pH}$ (117). It is therefore expected that human BAT is activated by nociceptive stimuli, including TRPV1 activation. In agreement with this concept, chronic adrenergic stress induced by burn trauma results in browning of white adipose tissue (118). Hence, it is conceivable that oral ingestion of capsinoids would lead to the activation of BAT thermogenesis through the TRPV1-mediated pathway in humans, whereas cold exposure would be more potent in inducing BAT activation than capsinoid ingestion (113). In light of a recent report claiming that capsinoid treatment in mice potentiates cold-induced browning of white fat (119), a combination of capsinoid supplementation and mild cold exposure may be an effective strategy for recruitment of BAT in humans.

\section{ACTIVATION AND RECRUITMENT OF BAT BY TEA CAFFEINE AND CATECHINS}

Other intriguing food ingredients that activate BAT thermogenesis are caffeine and catechins, which are abundantly found in green tea. Tea is made from the leaves of Camellia sinensis L., a species belonging to the Theaceae family. The manufacturing process produces various types of tea such as non-oxidized, non-fermented green tea, semifermented Oolong tea, and fermented black and red teas. These teas, particularly green tea, contain relatively large amounts of polyphenols, such as epicatechin and epigallocatechin gallate, which have various health benefits such as antiobesity, anticarcinogenic, and antibacterial properties $(120,121)$.

An apparent thermogenic effect of green tea extract in humans was reported first by Dulloo et al. (122). They demonstrated that ingestion of green tea extract containing catechins and caffeine elicited a $4 \%$ increase in 24 -h EE coupled with an increase in fat oxidation. Ingestion of caffeine alone had only a very slight effect on $\mathrm{EE}$, implying that the effects of green tea extract is mainly attributable to thermogenesis by catechins. Since then, the shortterm thermogenic effects of green tea extract and/or catechins have been confirmed by several studies using various doses of the extract and duration (123-125). Their long-term effects on body fatness have also been repeatedly investigated. For example, Nagao et al. (126) reported a small (2-3\%) but significant reduction of body fat content in a group of Japanese volunteers who underwent 12 weeks of treatment with green tea extract containing catechins. Similar fat-reducing effects of catechins were also confirmed in other studies (127-130), although there is also a report showing that there was no significant effect (131).

Although the possible involvement of BAT in the thermogenic and antiobesity effects of catechins has been suggested (132, 133), no evidence supporting this claim has been reported in humans. Recently, we found that an oral ingestion of catechin-rich tea produced a rapid increase in EE in individuals with higher BAT activities, but not in those with undetectable BAT activities (134). Moreover, a 5-week daily ingestion of catechin-rich tea resulted in a significant increase in CIT, an index of BAT activity. Although the active and placebo beverages contained a moderate amount of caffeine, the placebo ingestion did not produce any change in EE and CIT. The chronic effects of catechins on BAT were also confirmed using the NIRSTRS technique (135). Thus, it is highly likely that the observed thermogenesis is attributable to catechin, rather than caffeine. However, this does not rule out a possible synergistic action between catechins and caffeine $(136,137)$. Collectively, the thermogenic and fat-reducing effects of green tea extract rich in catechins would be attributable to the activation of BAT.

The thermogenic response to green tea extract has been proposed to be mediated through the direct stimulation of the NA- $\beta$ AR cascade in BAT by inhibiting a catecholaminedegrading enzyme, catechol-O-methyl transferase (COMT), by catechins and a cAMP-degrading enzyme, phosphodiesterase, by caffeine (133). In support of this claim, Velickovic et al. (138) demonstrated a temperature increase in the supraclavicular region, which colocates to the main region of BAT, after intake of caffeine-rich coffee. However, COMT activity may not be impaired by oral catechin ingestion in humans (139), because of the much lower circulating levels of catechins after a single ingestion ( $\sim 0.1 \mu \mathrm{M}$ at maximum) (140) compared with the half-maximal inhibitory concentration for the COMT activity $(\sim 14 \mu \mathrm{M})(141)$. Thus, the role of COMT inhibition as a primary target of the catechin action on BAT thermogenesis remains controversial. To this end, it is interesting that Kurogi et al. $(142,143)$ reported that green tea epigallocatechin gallate and its auto-oxidation products activated TRPV1 and TRP ankyrin subfamily member 1 (TRPA1), another member of the TRP family, in intestinal enteroendocrine cells at concentrations comparable to those in the gastrointestinal tract after oral ingestion. It is thus possible that catechins activate and recruit BAT through the action on TRPV1/TRPA1 in sensory neurons in the gastrointestinal tract, in the same manner as capsinoids; however, further studies are necessary to confirm this theory. 


\section{THE TRP-BAT AXIS AS A TARGET OF ANTIOBESITY FOOD INGREDIENTS}

In addition to capsaicin, capsinoids, and catechins, there are other food ingredients, particularly those in spicy foods, with agonistic activity to TRPV1 (144). For example, piperine is responsible for the pungency of black and white pepper; meanwhile, gingerols, shogaol, zingerone, and 6-paradol are found in ginger, some of which might be expected to activate BAT thermogenesis and reduce body fat. The seeds of Grains of Paradise [Aframomumu melegueta [Rosco] K. Schum.] (GP), which is also known as Guinea pepper or alligator pepper, are rich in 6-paradol and are commonly used as a spice for flavoring food; they also have a wide range of ethnobotanical uses (145). In humans, we found thermogenic responses to oral ingestion of an alcohol extract of GP in individuals with metabolically active BAT, but not in those without it (146), implying a BATdependent thermogenesis by GP extract. In line with the acute effects, in one study, daily ingestion of GP extract for 4 weeks resulted in a slight reduction in visceral fat (147). These results suggest that GP, like capsinoids and catechins, increases wholebody EE through the activation of BAT, thereby decreasing body fatness.

As noted above, TRPV1 is not a cold sensor, but a sensor of noxious hot temperatures higher than $43^{\circ} \mathrm{C}$. Among the members of the TRP family, TRP metastatin 8 (TRPM8) and TRPA1 are the most likely receptor candidates to be sensitive to lower temperatures. As the mean activation temperatures of these two TRPs are lower than $17-25^{\circ} \mathrm{C}$, chemical activation of these receptors is expected to mimic the effects of a mild cold exposure. A representative TRPM8 agonist is menthol, a cooling and flavor compound in mint. Application of menthol to the skin of whole trunk in mice was shown to induce autonomic and BAT responses, but at a much lower extent in TRPM8-deficient mice (148). A rapid increase in core and BAT temperatures was also observed after intragastric administration of menthol and 1,8cineole, another TRPM8 agonist (149). Using mice lacking either TRPM8 or UCP1, Ma et al. (150) reported that a diet supplemented with menthol enhances UCP1-dependent thermogenesis and prevents high-fat diet-induced obesity in a TRPM8-dependent manner. In humans, a slight but significant elevation of metabolic rate after a single skin menthol administration was observed (151), although its relation to BAT was not investigated.

TRPA1 is activated by various pungent compounds, such as ally- and benzyl-isothiocyanates in mustard and wasabi (Japanese horseradish) and cinnamaldehyde in cinnamon or dried bark of cassia. These compounds are known to increase thermogenesis and UCP1 expression, and decrease body fat $(149,152,153)$. In addition to these food ingredients, there are various natural compounds having agonistic activity for TRPM8 and TRPA1, some of which may also have the potential to activate BAT thermogenesis and reduce body fat. However, despite the evidence for BAT activation by these food ingredients in small rodents, their thermogenic and antiobesity effects, particularly those on BAT, have yet to be elucidated in humans.

\section{CONCLUSION AND PERSPECTIVE}

Since the rediscovery of metabolically active BAT in adult humans, BAT has been attracting increasing attention as a promising target for combating obesity and related diseases. In fact, several drugs targeting BAT have been tested for pharmacotherapy of obesity (154). In physiological terms, BAT thermogenesis is activated either by exposure to cold temperatures or after meal intake, but diet-induced BAT activation may contribute more significantly to whole-body EE in our usual daily life. As discussed above, BAT is activated by various postprandially secreted humoral factors such as BA and gut hormones, and by certain food ingredients acting on the TRP-SNS axis. Recent studies have shown that BAT is also involved in the regulation of systemic glucose and lipid homeostasis, directly by its intrinsic metabolic activity and probably through some BAT-derived humoral factors "batokines" (155). This may explain why some TRP agonists including capsinoids ameliorate insulin sensitivity and glucose homeostasis (156). Given the beneficial effects of various food ingredients and BA on substrate and energy metabolism, compounds activating the TRP/TGR5-BAT axis, by themselves and/or in combination with some drug, represent a promising option for combating obesity and related metabolic disorders.

In addition to the food ingredients discussed above, various food compounds such as curcumin, quercetin, thyme, allicin, retinoid acid, and resveratrols have been reported to activate and recruit BAT thermogenesis via multiple actions of mechanism that are either similar to or distinct from TRP-mediated processes $(157,158)$. Interestingly, the effects of some of these compounds including EPA are suggested to be mediated through the production of microRNAs $(96,159)$. However, most of these effects have been observed in studies using cells in vitro and mice/rats in vivo, whereas comparative evidence in humans is very limited. One of the reasons for this large gap may be related to the method used in assessing human BAT. To date, FDG-PET/CT is a standard tool used to measure human BAT (160); however, this option has serious limitations, including the enormous cost of the devices, radiation exposure, and acute cold exposure, which make repeated measurements difficult and an impediment in basic and clinical studies. There is therefore an urgent need to establish less invasive and simpler methods for quantitative assessment of human BAT. This would promote the development of practical, easy, and effective antiobesity regimens, particularly when searching for dietary factors/food ingredients that can activate and recruit BAT in humans.

\section{AUTHOR CONTRIBUTIONS}

MS wrote the first draft of the manuscript. TY reviewed the manuscript and drafted the figures. $\mathrm{MM}$ and $\mathrm{YO}-\mathrm{O}$ critically reviewed the manuscript.

\section{FUNDING}

This study was supported by a Grant-in-Aid for Scientific Research from the Ministry of Education, Culture, Sports, Science, and Technology of Japan (Nos. 22590227, 24240092, 26860703, 16K15485, 18K11013). 


\section{REFERENCES}

1. Cannon B, Nedergaard J. Brown adipose tissue: function and physiological significance. Physiol Rev. (2004) 84:277-359. doi: 10.1152/physrev.00015.2003

2. Saito M, Okamatsu-Ogura Y, Matsushita M, Watanabe K, Yoneshiro T, NioKobayashi J, et al. High incidence of metabolically active brown adipose tissue in healthy adult humans: effects of cold exposure and adiposity. Diabetes. (2009) 58:1526-31. doi: 10.2337/db09-0530

3. van Marken Lichtenbelt WD, Vanhommerig JW, Smulders NM, Drossaerts JM, Kemerink GJ, Bouvy ND, et al. Cold-activated brown adipose tissue in healthy men. N. Engl J Med. (2009) 360:1500-8. doi: 10.1056/NEJMoa0808718

4. Cypess AM, Lehman S, Williams G, Tal I, Rodman D, Goldfine AB, et al. Identification and importance of brown adipose tissue in adult humans. $N$ Engl J Med. (2009) 360:1509-17. doi: 10.1056/NEJMoa0810780

5. Virtanen KA, Lidell ME, Orava J, Heglind M, Westergren R, Niemi T, et al. Functional brown adipose tissue in healthy adults. N Engl J Med. (2009) 360:1518-25. doi: 10.1056/NEJMoa0808949

6. Kajimura S, Saito M. A new era in brown adipose tissue biology: molecular control of brown fat development and energy homeostasis. Annu Rev Physiol. (2014) 76:225-49. doi: 10.1146/annurev-physiol-021113-170252

7. Carpentier AC, Blondin DP, Virtanen KA, Richard D, Haman F, Turcotte EE. Brown adipose tissue energy metabolism in humans. Front Endocrinol. (2018) 9:447. doi: 10.3389/fendo.2018.00447

8. Cypess AM, Weiner LS, Roberts-Toler C, Franquet Elia E, Kessler SH, Kahn PA, et al. Activation of human brown adipose tissue by a $\beta 3$-adrenergic receptor agonist. Cell Metab. (2015) 21:33-8. doi: 10.1016/j.cmet.2014.12.009

9. Yoneshiro T, Aita S, Matsushita M, Kameya T, Nakada K, Kawai Y, et al. Brown adipose tissue, whole-body energy expenditure, and thermogenesis in healthy adult men. Obesity. (2011) 19:13-6. doi: 10.1038/oby.2010.105

10. Orava J, Nuutila P, Lidell ME, Oikonen V, Noponen T, Viljanen $\mathrm{T}$, et al. Different metabolic responses of human brown adipose tissue to activation by cold and insulin. Cell Metab. (2011) 14:272-9. doi: 10.1016/j.cmet.2011.06.012

11. Ouellet V, Labbe SM, Blondin DP, Phoenix S, Guerin B, Haman F, et al. Brown adipose tissue oxidative metabolism contributes to energy expenditure during acute cold exposure in humans. J Clin Invest. (2012) 122:545-52. doi: 10.1172/JCI60433

12. Chen KY, Brychta RJ, Linderman JD, Smith S, Courville A, Dieckmann W, et al. Brown fat activation mediates cold-induced thermogenesis in adult humans in response to a mild decrease in ambient temperature. J Clin Endocrinol Metab. (2013) 98:E1218-23. doi: 10.1210/jc.2012-4213

13. Pfannenberg C, Werner MK, Ripkens S, Stef I, Deckert A, Schmadl M, et al. Impact of age on the relationships of brown adipose tissue with sex and adiposity in humans. Diabetes. (2010) 59:1789-93. doi: 10.2337/db10-0004

14. Ouellet V, Routhier-Labadie A, Bellemare W, Lakhal-Chaieb L, Turcotte E, Carpentier AC, et al. Outdoor temperature, age, sex, body mass index, and diabetic status determine the prevalence, mass, and glucose-uptake activity of 18F-FDG-detected BAT in humans. J Clin Endocrinol Metab. (2011) 96:192-9. doi: 10.1210/jc.2010-0989

15. Persichetti A, Sciuto R, Rea S, Basciani S, Lubrano C, Mariani S, et al. Prevalence, mass, and glucose-uptake activity of (1)(8)F-FDG-detected brown adipose tissue in humans living in a temperate zone of Italy. PLoS ONE. (2013) 8:e63391. doi: 10.1371/journal.pone.0063391

16. Zhang Q, Ye H, Miao Q, Zhang Z, Wang Y, Zhu X, et al. Differences in the metabolic status of healthy adults with and without active brown adipose tissue. Wien Klin Wochenschr. (2013) 125:687-95. doi: 10.1007/s00508-013-0431-2

17. Yoneshiro T, Aita S, Matsushita M, Okamatsu-Ogura Y, Kameya T, Kawai $\mathrm{Y}$, et al. Age-related decrease in cold-activated brown adipose tissue and accumulation of body fat in healthy humans. Obesity. (2011) 19:1755-60. doi: 10.1038/oby.2011.125

18. Yoneshiro T, Aita S, Matsushita M, Kayahara T, Kameya T, Kawai $\mathrm{Y}$, et al. Recruited brown adipose tissue as an antiobesity agent in humans. J Clin Invest. (2013). 123:3404-8. doi: 10.1172/JCI 67803
19. van der Lans AA, Hoeks J, Brans B, Vijgen GH, Visser MG, Vosselman MJ, et al. Cold acclimation recruits human brown fat and increases nonshivering thermogenesis. J Clin Invest. (2013) 123:3395-403. doi: 10.1172/JCI68993

20. Blondin DP, Labbe SM, Tingelstad HC, Noll C, Kunach M, Phoenix $\mathrm{S}$, et al. Increased brown adipose tissue oxidative capacity in coldacclimated humans. J Clin Endocrinol Metab. (2014) 99:E438-46. doi: 10.1210/jc.2013-3901

21. Lee P, Smith S, Linderman J, Courville AB, Brychta RJ, Dieckmann W, et al. Temperature-acclimated brown adipose tissue modulates insulin sensitivity in humans. Diabetes. (2014) 63:3686-98. doi: 10.2337/db14-0513

22. Chondronikola M, Volpi E, Borsheim E, Porter C, Annamalai P, Enerback S, et al. Brown adipose tissue improves whole-body glucose homeostasis and insulin sensitivity in humans. Diabetes. (2014) 63:4089-99. doi: $10.2337 / \mathrm{db} 14-0746$

23. Matsushita M, Yoneshiro T, Aita S, Kameya T, Sugie H, Saito M. Impact of brown adipose tissue on body fatness and glucose metabolism in healthy humans. Int J Obes. (2014) 38:812-7. doi: 10.1038/ijo.2013.206

24. Hanssen MJ, Hoeks J, Brans B, van der Lans AA, Schaart G, van den Driessche JJ, et al. Short-term cold acclimation improves insulin sensitivity in patients with type 2 diabetes mellitus. Nat Med. (2015) 21:863-65. doi: $10.1038 / \mathrm{nm} .3891$

25. Saito M. Brown adipose tissue as a regulator of energy expenditure and body fat in humans. Diabetes Metab J. (2013) 37:22-9. doi: 10.4093/dmj.2013.37.1.22

26. Yoneshiro T, Saito M. Activation and recruitment of brown adipose tissue as anti-obesity regimens in humans. Ann Med. (2015) 47:133-41. doi: 10.3109/07853890.2014.911595

27. Lidell ME, Betz MJ, Enerback S. Brown adipose tissue and its therapeutic potential. J Intern Med. (2014) 276:364-77. doi: 10.1111/joim.12255

28. Chechi K, Nedergaard J, Richard D. Brown adipose tissue as an anti-obesity tissue in humans. Obes Rev. (2014) 15:92-106. doi: 10.1111/obr.12116

29. Sidossis L, Kajimura S. Brown and beige fat in humans: thermogenic adipocytes that control energy and glucose homeostasis. J Clin Invest. (2015) 125:478-86. doi: 10.1172/JCI78362

30. Heeren J, Scheja L. Brown adipose tissue and lipid metabolism. Curr Opin Lipidol. (2018) 29:180-5. doi: 10.1097/MOL.0000000000000504

31. Dong M, Yang X, Lim S, Cao Z, Honek J, Lu H, et al. Cold exposure promotes atherosclerotic plaque growth and instability via UCP1-dependent lipolysis. Cell Metab. (2013) 18:118-29. doi: 10.1016/j.cmet.2013.06.003

32. Dhaka A, Viswanath V, Patapoutian A. Trp ion channels and temperature sensation. Annu Rev Neurosci. (2006) 29:135-61. doi: 10.1146/annurev.neuro.29.051605.112958

33. Nakamura K. Central circuitries for body temperature regulation and fever. Am J Physiol Regul Integr Comp Physiol. (2011) 301:R1207-28. doi: 10.1152/ajpregu.00109.2011

34. Inokuma K, Ogura-Okamatsu Y, Toda C, Kimura K, Yamashita H, Saito M. Uncoupling protein 1 is necessary for norepinephrine-induced glucose utilization in brown adipose tissue. Diabetes. (2005) 54:1385-91. doi: $10.2337 /$ diabetes.54.5.1385

35. Bukowiecki LJ, Geloen A, Collet AJ. Proliferation and differentiation of brown adipocytes from interstitial cells during cold acclimation. Am J Physiol. (1986) 250:C880-7. doi: 10.1152/ajpcell.1986.250.6.C880

36. Okamatsu-Ogura Y, Fukano, K, Tsubota A, Nio-Kobayashi, Y, Nakamura $\mathrm{K}$, Morimatsu M, et al. Cell-cycle arrest in mature adipocytes impairs BAT development but not WAT browning, and reduces adaptive thermogenesis in mice. Sci Rep. (2017) 7:6648. doi: 10.1038/s41598-017-07206-8

37. Harms M, Seale P. Brown and beige fat: development, function and therapeutic potential. Nat Med. (2013) 19:1252-63. doi: 10.1038/nm.3361

38. Finlin BS, Memetimin H, Confides AL, Kasza I, Zhu B, Vekaria HJ, et al. Human adipose beiging in response to cold and mirabegron. JCI Insight. (2018) 3:e121510. doi: 10.1172/jci.insight.121510

39. Sharp LZ, Shinoda K, Ohno H, Scheel DW, Tomoda E, Ruiz L, et al. Human BAT possesses molecular signatures that resemble beige/brite cells. PLoS ONE. (2012) 7:e49452. doi: 10.1371/journal.pone.0049452

40. Lidell ME, Betz MJ, Dahlqvist Leinhard O, Heglind M, Elander L, Slawik M, et al. Evidence for two types of brown adipose tissue in humans. Nat Med. (2013) 19:631-4. doi: 10.1038/nm.3017 
41. Cypess AM, White AP, Vernochet C, Schulz TJ, Xue R, Sass CA, et al. Anatomical localization, gene expression profiling and functional characterization of adult human neck brown fat. Nat Med. (2013) 19:635-9. doi: $10.1038 / \mathrm{nm} .3112$

42. Rothwell NJ, Stock MJ. A role for brown adipose tissue in diet-induced thermogenesis. Nature. (1979) 281:31-5. doi: 10.1038/281031a0

43. Fromme T, Klingenspor M. Uncoupling protein 1 expression and highfat diets. Am J Physiol Regul Integr Comp Physiol. (2011) 300:R1-8. doi: 10.1152/ajpregu.00411.2010

44. von Essen G, Lindsund E, Cannon B, Nedergaard J. Adaptive facultative diet-induced thermogenesis in wild-type but not in UCP1ablated mice. Am J Physiol Endocrinol Metab. (2017) 313:E515-27. doi: 10.1152/ajpendo.00097.2017

45. Kozak LP. Brown fat and the myth of diet-induced thermogenesis. Cell Metab. (2010) 11:263-7. doi: 10.1016/j.cmet.2010.03.009

46. Glick Z, Teague RJ, Bray GA. Brown adipose tissue: thermic response increased by a single low protein, high carbohydrate meal. Science. (1981) 213:1125-7. doi: 10.1126/science.7268419

47. Lupien JR, Glick Z, Saito M, Bray GA. Guanosine diphosphate binding to brown adipose tissue mitochondria is increased after single meal. Am J Physiol. (1985) 249:R694-8. doi: 10.1152/ajpregu.1985.249.6.R694

48. Saito M, Minokoshi Y, Shimazu T. Metabolic and sympathetic nerve activities of brown adipose tissue in tube-fed rats. Am J Physiol. (1989) 257:E374-8. doi: 10.1152/ajpendo.1989.257.3.E374

49. Oppert JM, Vohl MC, Chagnon M, Dionne FT, Cassard-Doulcier AM, Ricquier D, et al. DNA polymorphism in the uncoupling protein (UCP) gene and human body fat. Int J Obes Relat Metab Disord. (1994) 18:526-31.

50. Valve R, Heikkinen S, Rissanen A, Laakso M, Uusitupa M. Synergistic effect of polymorphisms in uncoupling protein 1 and beta3-adrenergic receptor genes on basal metabolic rate in obese Finns. Diabetologia. (1998) 41:357-61. doi: 10.1007/s001250050915

51. Kogure A, Yoshida T, Sakane N, Umekawa T, Takakura Y, Kondo M. Synergic effect of polymorphisms in uncoupling protein 1 and beta3adrenergic receptor genes on weight loss in obese Japanese. Diabetologia. (1998) 41:1399. doi: 10.1007/s001250051084

52. Yoneshiro T, Ogawa T, Okamoto N, Matsushita M, Aita S, Kameya T, et al. Impact of UCP1 and $\beta 3 \mathrm{AR}$ gene polymorphisms on age-related changes in brown adipose tissue and adiposity in humans. Int J Obes. (2013) 37:993-8. doi: 10.1038/ijo.2012.161

53. Nagai N, Sakane N, Ueno LM, Hamada T, Moritani T. The-3826 A$>\mathrm{G}$ variant of the uncoupling protein-1 gene diminishes postprandial thermogenesis after a high fat meal in healthy boys. J Clin Endocrinol Metab. (2003) 88:5661-7. doi: 10.1210/jc.2003-030672

54. Nagai N, Sakane N, Fujishita A, Fujiwara R, Kimura T, Kotani K, et al. The-3826 A $->$ G variant of the uncoupling protein-1 gene diminishes thermogenesis during acute cold exposure in healthy children. Obes Res Clin Pract. (2007) 1:99-107. doi: 10.1016/j.orcp.2007.02.001

55. Vrieze A, Schopman JE, Admiraal WM, Soeters MR, Nieuwdorp $\mathrm{M}$, Verberne HJ, et al. Fasting and postprandial activity of brown adipose tissue in healthy men. J Nucl Med. (2012) 53:1407-10. doi: 10.2967/jnumed.111.100701

56. Vosselman MJ, Brans B, van der Lans AA, Wierts R, van Baak MA, Mottaghy FM, et al. Brown adipose tissue activity after a high-calorie meal in humans. Am J Clin Nutr. (2013) 98:57-64. doi: 10.3945/ajcn.113. 059022

57. Muzik O, Mangner TJ, Leonard WR, Kumar A, Janisse J, Granneman JG. 15O PET measurement of blood flow and oxygen consumption in cold-activated human brown fat. J Nucl Med. (2013) 54:523-31. doi: $10.2967 /$ jnumed.112.111336

58. Din MU, Saari T, Raiko J, Kudomi N, Maurer SF, Lahesmaa $\mathrm{M}$, et al. Postprandial oxidative metabolism of human brown fat indicates thermogenesis. Cell Metab. (2018) 28:207-16. doi: 10.1016/j.cmet.2018.05.020

59. Hibi M, Oishi S, Matsushita M, Yoneshiro T, Yamaguchi T, Usui C, et al. Brown adipose tissue is involved in diet-induced thermogenesis and whole-body fat utilization in healthy humans. Int J Obes. (2016) 40:1655-61. doi: 10.1038/ijo.2016.124
60. Glick Z, Raum WJ. Norepinephrine turnover in brown adipose tissue is stimulated by a single meal. Am J Physiol. (1986) 251:R13-7. doi: 10.1152/ajpregu.1986.251.1.R13

61. Schwartz RS, Jaeger LF, Silberstein S, Veith RC. Sympathetic nervous system activity and the thermic effect of feeding in man. Int J Obes. (1987) 11:141-9.

62. Welle S, Lilavivat U, Campbell RG. Thermic effect of feeding in man: increased plasma norepinephrine levels following glucose but not protein or fat consumption. Metabolism. (1981) 30:953-8. doi: 10.1016/0026-0495(81)90092-5

63. van Baak MA. Meal-induced activation of the sympathetic nervous system and its cardiovascular and themogenic effects in man. Physiol Behav. (2008) 94:178-86. doi: 10.1016/j.physbeh.2007.12.020

64. Young JB, Saville E, Rothwell NJ, Stock MJ, Landsberg L. Effect of diet and cold exposure on norepinephrine turnover in brown adipose tissue of the rat. J Clin Invest. (1982) 69:1061-71. doi: 10.1172/JCI110541

65. Yoshida T, Fisler JS, Fukushima M, Bray GA, Schemmel RA. Diet, lighting, and food intake affect norepinephrine turnover in dietary obesity. Am J Physiol. (1987) 252:R402-8. doi: 10.1152/ajpregu.1987.252.2.R402

66. LeBlanc J, Cabanac M, Samson P. Reduced postprandial heat production with gavage as compared with meal feeding in human subjects. Am J Physiol. (1984) 246:E95-101. doi: 10.1152/ajpendo.1984.246.1.E95

67. Diamond P, Brondel L, LeBlanc J. Palatability and postprandial thermogenesis in dogs. Am J Physiol. (1985) 248:E75-9. doi: 10.1152/ajpendo.1985.248.1.E75

68. LeBlanc J, Brondel L. Role of palatability on meal-induced thermogenesis in human subjects. Am J Physiol. (1985) 248:E333-6. doi: 10.1152/ajpendo.1985.248.3.E333

69. Wijers SL, Saris WH, van Marken Lichtenbelt WD. Individual thermogenic responses to mild cold and overfeeding are closely related. J Clin Endocrinol Metab. (2007) 92:4299-305. doi: 10.1210/jc.2007-1065

70. Peterson CM, Lecoultre V, Frost EA, Simmons J, Redman LM, Ravussin E. The thermogenic responses to overfeeding and cold are differentially regulated. Obesity. (2016) 24:96-101. doi: 10.1002/oby.21233

71. Zwillich C, Martin B, Hofeldt F, Charles A, Subryan V, Burman K. Lack of effects of beta sympathetic blockade on the metabolic and respiratory responses to carbohydrate feeding. Metabolism. (1981) 30:451-6. doi: 10.1016/0026-0495(81)90179-7

72. Welle S, Campbell RG. Stimulation of thermogenesis by carbohydrate overfeeding. Evidence against sympathetic nervous system mediation. J Clin Invest. (1983) 71:916-25. doi: 10.1172/JCI110846

73. Thorne A, Wahren J. Beta-adrenergic blockade does not influence the thermogenic response to a mixed meal in man. Clin Physiol. (1989) 9:321-32. doi: 10.1111/j.1475-097X.1989.tb00986.x

74. Li Y, Schnabl K, Gabler SM, Willershauser M, Reber J, Karlas A, et al. Secretin-activated brown fat mediates prandial thermogenesis to induce satiation. Cell. (2018) 175:1561-74. doi: 10.1016/j.cell.2018.10.016

75. Yamazaki T, Morimoto-Kobayashi Y, Koizumi K, Takahashi C, Nakajima S, Kitao S, et al. Secretion of a gastrointestinal hormone, cholecystokinin, by hop-derived bitter components activates sympathetic nerves in brown adipose tissue. J Nutr Biochem. (2019) 64:80-7. doi: 10.1016/j.jnutbio.2018.10.009

76. Blouet C, Schwartz GJ. Duodenal lipid sensing activates vagal afferents to regulate non-shivering brown fat thermogenesis in rats. PLOS ONE. (2012) 7:e51898. doi: 10.1371/journal.pone.0051898

77. Vijgen GH, Bouvy ND, Leenen L, Rijkers K, Cornips E, Majoie $\mathrm{M}$, et al. Vagus nerve stimulation increases energy expenditure: relation to brown adipose tissue activity. PLOS ONE. (2013) 8:e77221. doi: 10.1371/journal.pone.0077221

78. Lin L, Lee JH, Bongmba OY, Ma X, Zhu X, Sheikh-Hamad D, et al. The suppression of ghrelin signaling mitigates age-associated thermogenic impairment. Aging. (2014) 6:1019-32. doi: 10.18632/aging.100706

79. Chondronikola M, Porter C, Malagaris I, Nella AA, Sidossis LS. Brown adipose tissue is associated with systemic concentrations of peptides secreted from the gastrointestinal system and involved in appetite regulation. Eur J Endocrinol. (2017) 177:33-40. doi: 10.1530/EJE-16-0958

80. Haeusler RA, Camastra S, Nannipieri M, Astiarraga B, Castro-Perez J, Xie D, et al. Increased bile acid synthesis and impaired bile acid 
transport in human obesity. J Clin Endocrinol Metab. (2016) 101, 935-44. doi: 10.1210/jc.2015-2583

81. Sonne DP, van Nierop FS, Kulik W, Soeters MR, Vilsbøll T, Knop FK, et al. Postprandial plasma concentrations of individual bile acids and FGF-19 in patients with type 2 diabetes. J Clin Endocrinol Metab. (2016) 101:3002-9. doi: 10.1210/jc.2016-1607

82. Vítek L, Haluzík M. The role of bile acids in metabolic regulation. $J$ Endocrinol. (2016) 228:R85-96. doi: 10.1530/JOE-15-0469

83. Watanabe M, Houten SM, Mataki C, Christoffolete MA, Kim BW, Sato H, et al. Bile acids induce energy expenditure by promoting intracellular thyroid hormone activation. Nature. (2006) 439:484-9. doi: 10.1038/nature04330

84. Broeders EPM, Nascimento EBM, Bas Havekes B, Brans B, Roumans KHM, Tailleux A, et al. The bile acid chenodeoxycholic acid increases human brown adipose tissue activity. Cell Metabolism. (2015) 22:418-26. doi: 10.1016/j.cmet.2015.07.002

85. Beiroa D, Imbernon M, Gallego R, Senra A, Herranz D, Villarroya F, et al. GLP-1 agonism stimulates brown adipose tissue thermogenesis and browning through hypothalamic AMPK. Diabetes. (2014) 63:3346--58. doi: $10.2337 / \mathrm{db} 14-0302$

86. Zhou J, Poudel A, Chandramani-Shivalingappa P, Biao Xu B, Ryan Welchko R, Li L. Liraglutide induces beige fat development and promotes mitochondrial function in diet induced obesity mice partially through AMPK-SIRT-1-PGC1- $\alpha$ cell signaling pathway. Endocrine. (2019) 64:27183. doi: 10.1007/s12020-018-1826-7

87. Velazquez-Villegas LA, Perino A, Vera Lemos V, Zietak M, Nomura M, Willem $\mathrm{T}$, et al. TGR5 signalling promotes mitochondrial fission and beige remodelling of white adipose tissue. Nat Commun. (2018) 9:245. doi: 10.1038/s41467-017-02068-0

88. Vander Tuig JG, Romsos DR. Effects of dietary carbohydrate, fat, and protein on norepinephrine turnover in rats. Metabolism. (1984) 33:26-33. doi: 10.1016/0026-0495(84)90158-6

89. Johnston JL, Balachandran AV. Effects of dietary protein, energy and tyrosine on central and peripheral norepinephrine turnover in mice. J Nutr. (1987) 117:2046-53. doi: 10.1093/jn/117.12.2046

90. Bender N, Portmann M, Heg Z, Hofmann K, Zwahlen M, Egger M. Fish or n3-PUFA intake and body composition: a systematic review and metaanalysis. Obes Rev. (2014) 15:657-65. doi: 10.1111/obr.12189

91. Clevenger HC, Kozimor AL, Paton CM, Cooper JA. Acute effect of dietary fatty acid composition on postprandial metabolism in women. Exp Physiol. (2014) 99:1182-90. doi: 10.1113/expphysiol.2013.077222

92. Cisneros LCV, Moreno AGM, Lopez-Espinoza A, Espinoza-Gallardo AC. Effect of the fatty acid composition of meals on postprandial energy expenditure: a systematic review. Rev Assoc Med Bras. (1992) 65:1022-31. doi: 10.1590/1806-9282.65.7.1022

93. Oudart H, Groscolas R, Calgari C, Nibbelink M, Leray C, Le Maho Y, et al. Brown fat thermogenesis in rats fed high-fat diets enriched with n-3 polyunsaturated fatty acids. Int J Obes Relat Metab Disord. (1997) 21:955-62. doi: 10.1038/sj.ijo.0800500

94. Kawada T, Kayahashi S, Hida Y, Koga K, Nadachi Y, Fushiki T. Fish (bonito) oil supplementation enhances the expression of uncoupling protein in brown adipose tissue of rat. J Agric Food Chem. (1998) 46:1225-7. doi: $10.1021 /$ jf9711000

95. Kim M, Goto T, Yu R, Uchida K, Tominaga M, Kano Y, et al. Fish oil intake induces UCP1 upregulation in brown and white adipose tissue via the sympathetic nervous system. Sci Rep. (2015) 5:18013. doi: 10.1038/srep18013

96. Kim J, Okla M, Erickson A, Carr T, Natarajan SK, Chung S. Eicosapentaenoic acid potentiates brown thermogenesis through FFAR4-dependent upregulation of miR-30b and miR-378. J Biol Chem. (2016) 291:20551-62. doi: $10.1074 /$ jbc.M116.721480

97. Ghandour RA, Colson C, Giroud M, Maurer S, Rekima S, Ailhaud G, et al. Impact of dietary omega3 polyunsaturated fatty acid supplementation on brown and brite adipocyte function. J Lipid Res. (2018) 59:452-61. doi: 10.1194/jlr.M081091

98. Leiria LO, Wang CH, Lynes MD, Yang K, Shamsi F, Sato M, et al. 12-Lipoxygenase regulates cold adaptation and glucose metabolism by producing the omega-3 lipid 12-HEPE from brown fat. Cell Metab. (2019) 30:768-83. doi: 10.1016/j.cmet.2019.07.001
99. Lv J, Qi L, Yu C, Yang L, Guo Y, Chen Y, et al. Consumption of spicy foods and total and cause specific mortality: population based cohort study. BMJ. (2015). 351:h3942. doi: 10.1136/bmj.h3942

100. Ludy MJ, Moore GE, Mattes RD. The effects of capsaicin and capsiate on energy balance: critical review and meta-analyses of studies in humans. Chem Senses. (2012) 37:103-21. doi: 10.1093/chemse/bjr100

101. Tremblay A, Arguin H, Panahi S. Capsaicinoids: a spicy solution to the management of obesity? Int J Obes. (2016) 40:1198-204. doi: 10.1038/ijo.2015.253

102. Watanabe T, Ohnuki K, Kobata K. Studies on the metabolism and toxicology of emerging capsinoids. Expert Opin Drug Metab Toxicol. (2011) 7:533-42. doi: 10.1517/17425255.2011.562193

103. Uchida K, Dezaki K, Yoneshiro T, Watanabe T, Yamazaki J, Saito M, et al. Involvement of thermosensitive TRP channels in energy metabolism. $J$ Physiol Sci. (2017) 67:549-60. doi: 10.1007/s12576-017-0552-x

104. Ono K, Tsukamoto-Yasui M, Hara-Kimura Y, Inoue N, Nogusa Y, Okabe Y, et al. Intragastric administration of capsiate, a transient receptor potential channel agonist, triggers thermogenic sympathetic responses. J Appl Physiol. (1985) 110:789-98. doi: 10.1152/japplphysiol.00128.2010

105. Kawabata F, Inoue N, Masamoto Y, Matsumura S, Kimura W, Kadowaki $\mathrm{M}$, et al. Non-pungent capsaicin analogs (capsinoids) increase metabolic rate and enhance thermogenesis via gastrointestinal TRPV1 in mice. Biosci Biotechnol Biochem. (2009) 73:2690-97. doi: 10.1271/bbb.90555

106. Kawada T, Watanabe T, Takaishi T, Tanaka T, Iwai K. Capsaicin-induced beta-adrenergic action on energy metabolism in rats: influence of capsaicin on oxygen consumption, the respiratory quotient, and substrate utilization. Proc Soc Exp Biol Med. (1986) 183:250-6. doi: 10.3181/00379727-183-42414

107. Baskaran P, Krishnan V, Ren J, Thyagarajan B. Capsaicin induces browning of white adipose tissue and counters obesity by activating TRPV1 channel-dependent mechanisms. Br J Pharmacol. (2016) 173:2369-89. doi: 10.1111/bph.13514

108. Okamatsu-Ogura Y, Tsubota A, Ohygma K, Nogusa Y, Saito M, Kimura K. Capsinoids suppress diet-induced obesity through uncoupling protein 1-dependent mechanism in mice. J Funct Foods. (2015) 19:1-9. doi: 10.1016/j.jff.2015.09.005

109. Baskaran P, Krishnan V, Fettel K, Gao P, Zhu Z, Ren J, et al. TRPV1 activation counters diet-induced obesity through sirtuin-1 activation and PRDM16 deacetylation in brown adipose tissue. Int J Obes. (2017) 41:739-49. doi: 10.1038/ijo.2017.16

110. Bernard BK, Tsubuku S, Kayahara T, Maeda K, Hamada M, Nakamura $\mathrm{T}$, et al. Studies of the toxicological potential of capsihnoids: X. safety assessment and pharmacokinetics of capsioids in healthy male volunteers after a single oral ingestion of CH-19 sweet extract. Int J Toxicol. (2008) 27(Suppl. 3):137-47. doi: 10.1080/10915810802514476

111. Yoneshiro T, Aita S, Kawai Y, Iwanaga T, Saito M. Nonpungent capsaicin analogs (capsinoids) increase energy expenditure through the activation of brown adipose tissue in humans. Am J Clin Nutr. (2012) 95:845-50. doi: 10.3945/ajcn.111.018606

112. Yoneshiro T, Matsushita M, Nakae S, Kameya T, Sugie H, Tanaka S, et al. Brown adipose tissue is involved in the seasonal variation of cold-induced thermogenesis in humans. Am J Physiol Regul Integr Comp Physiol. (2016) 310:R999-1009. doi: 10.1152/ajpregu.00057.2015

113. Sun L, Camps SG, Goh HJ, Govindharajulu P, Schaefferkoetter JD, Townsend DW, et al. Capsinoids activate brown adipose tissue (BAT) with increased energy expenditure associated with subthreshold 18fluorine fluorodeoxyglucose uptake in BAT-positive humans confirmed by positron emission tomography scan. Am J Clin Nutr. (2018) 107:62-70. doi: $10.1093 /$ ajcn/nqx025

114. Nirengi S, Homma T, Inoue N, Sato H, Yoneshiro T, Matsushita M, et al. Assessment of human brown adipose tissue density during daily ingestion of thermogenic capsinoids using near-infrared time-resolved spectroscopy. $J$ Biomed Opt. (2016) 21:091305. doi: 10.1117/1.JBO.21.9.091305

115. Nirengi S, Yoneshiro T, Sugie H, Saito M, Hamaoka T. Human brown adipose tissue assessed by simple, noninvasive near-infrared time-resolved spectroscopy. Obesity. (2015) 23:973-80. doi: 10.1002/oby.21012

116. Snitker S, Fujishima Y, Shen H, Ott S, Pi-Sunyer X, Furuhata Y, et al. Effects of novel capsinoid treatment on fatness and energy metabolism in humans: 
possible pharmacogenetic implications. Am J Clin Nutr. (2009) 89:45-50. doi: $10.3945 /$ ajcn.2008.26561

117. Tominaga M. Nociception and TRP channels. Handb Exp Pharmacol. (2007) 179:489-505. doi: 10.1007/978-3-540-34891-7_29

118. Sidossis LS, Porter C, Saraf MK, Borsheim E, Radhakrishnan RS, Chao $\mathrm{T}$, et al. Browning of subcutaneous white adipose tissue in humans after severe adrenergic stress. Cell Metab. (2015) 22:219-27. doi: 10.1016/j.cmet.2015.06.022

119. Ohyama K, Nogusa Y, Shinoda K, Suzuki K, Bannai M, Kajimura S. A synergistic antiobesity effect by a combination of capsinoids and cold temperature through promoting beige adipocyte biogenesis. Diabetes. (2016) 65:1410-23. doi: $10.2337 / \mathrm{db} 15-0662$

120. Cabrera C, Artacho R, Gimenez R. Beneficial effects of green tea-a review. J Am Coll Nutr. (2006) 25:79-99. doi: 10.1080/07315724.2006.10719518

121. Thavanesan N. The putative effects of green tea on body fat: an evaluation of the evidence and a review of the potential mechanisms. Br J Nutr. (2011) 106:1297-309. doi: 10.1017/S0007114511003849

122. Dulloo AG, Duret C, Rohrer D, Girardier L, Mensi N, Fathi M, et al. Efficacy of a green tea extract rich in catechin polyphenols and caffeine in increasing 24-h energy expenditure and fat oxidation in humans. Am J Clin Nutr. (1999) 70:1040-5. doi: 10.1093/ajcn/70.6.1040

123. Berube-Parent S, Pelletier C, Dore J, Tremblay A. Effects of encapsulated green tea and Guarana extracts containing a mixture of epigallocatechin-3gallate and caffeine on $24 \mathrm{~h}$ energy expenditure and fat oxidation in men. $\mathrm{Br}$ J Nutr. (2005) 94:432-6. doi: 10.1079/BJN20051502

124. Venables MC, Hulston CJ, Cox HR, Jeukendrup AE. Green tea extract ingestion, fat oxidation, and glucose tolerance in healthy humans. Am J Clin Nutr. (2008) 87:778-84. doi: 10.1093/ajcn/87.3.778

125. Hursel R, Viechtbauer W, Dulloo AG, Tremblay A, Tappy L, Rumpler $\mathrm{W}$, et al. The effects of catechin rich teas and caffeine on energy expenditure and fat oxidation: a meta-analysis. Obes Rev. (2011) 12:e573-81. doi: 10.1111/j.1467-789X.2011.00862.x

126. Nagao T, Hase T, Tokimitsu I. A green tea extract high in catechins reduces body fat and cardiovascular risks in humans. Obesity. (2007) 15:1473-83. doi: 10.1038/oby.2007.176

127. Hursel R, Viechtbauer W, Westerterp-Plantenga MS. The effects of green tea on weight loss and weight maintenance: a meta-analysis. Int J Obes. (2009) 33:956-61. doi: 10.1038/ijo.2009.135

128. Westerterp-Plantenga MS, Lejeune MP, Kovacs EM. Body weight loss and weight maintenance in relation to habitual caffeine intake and green tea supplementation. Obes Res. (2005) 13:1195-204. doi: 10.1038/oby.2005.142

129. Wang H, Wen Y, Du Y, Yan X, Guo H, Rycroft JA, et al. Effects of catechin enriched green tea on body composition. Obesity. (2010) 18:773-9. doi: 10.1038/oby.2009.256

130. Hibi M, Takase H, Iwasaki M, Osaki N, Katsuragi K. Efficacy of tea catechinrich beverages to reduce abdominal adiposity and metabolic syndrome risks in obese and overweight subjects: a pooled analysis of 6 human trials. Nutr Res. (2018) 55:1-10. doi: 10.1016/j.nutres.2018.03.012

131. Dostal AM, Arikawa A, Espejo L, Kurzer MS. Long-term supplementation of green tea extract does not modify adiposity or bone mineral density in a randomized trial of overweight and obese postmenopausal women. J Nutr. (2016) 146:256-64. doi: 10.3945/jn.115.219238

132. Nomura S, Ichinose T, Jinde M, Kawashima Y, Tachiyashiki K, Imaizumi $\mathrm{K}$. Tea catechins enhance the mRNA expression of uncoupling protein 1 in rat brown adipose tissue. J Nutr Biochem. (2008) 19:840-7. doi: 10.1016/j.jnutbio.2007.11.005

133. Dulloo AG. The search for compounds that stimulate thermogenesis in obesity management: from pharmaceuticals to functional food ingredients. Obes Rev. (2011) 12:866-83. doi: 10.1111/j.1467-789X.2011.00909.x

134. Yoneshiro T, Matsushita M, Hibi M, Tone H, Takeshita M, Yasunaga K, et al. Tea catechin and caffeine activate brown adipose tissue and increase cold-induced thermogenic capacity in humans. Am J Clin Nutr. (2017) 105:873-81. doi: 10.3945/ajcn.116.144972

135. Nirengi S, Amagasa S, Homma T, Yoneshiro T, Matsumiya S, Kurosawa $\mathrm{Y}$, et al. Daily ingestion of catechin-rich beverage increases brown adipose tissue density and decreases extramyocellular lipids in healthy young women. Springerplus. (2016) 5:1363. doi: 10.1186/s40064-016-3029-0
136. Westerterp-Plantenga MS. Green tea catechins, caffeine and body-weight regulation. Physiol Behav. (2010) 100:42-6. doi: 10.1016/j.physbeh.2010.02.005

137. Ferreira MA, Silva DM, de Morais AC Jr, Mota JF, Botelho PB. Therapeutic potential of green tea on risk factors for type 2 diabetes in obese adults - a review. Obes Rev. (2016) 17:1316-28. doi: 10.1111/obr.12452

138. Velickovic K, Wayne D, Leija HAL, Bloor I, Morris DE, Law J, et al. Caffeine exposure induces browning features in adipose tissue in vitro and in vivo. Sci Rep. (2019) 9:9104. doi: 10.1038/s41598-019-45540-1

139. Lorenz M, Paul F, Moobed M, Baumann G, Zimmermann BF, Stangl K, et al. The activity of catechol-O-methyltransferase (COMT) is not impaired by high doses of epigallocatechin-3-gallate (EGCG) in vivo. Eur J Pharmacol. (2014) 740:645-51. doi: 10.1016/j.ejphar.2014.06.014

140. Takahashi M, Miyashita M, Suzuki K, Bae SR, Kim HK, Wakisaka T, et al. Acute ingestion of catechin-rich green tea improves postprandial glucose status and increases serum thioredoxin concentrations in postmenopausal women. Br J Nutr. (2014) 112:1542-50. doi: 10.1017/S0007114514002530

141. Kadowaki M, Ootani E, Sugihara N, Furuno K. Inhibitory effects of catechin gallates on o-methyltranslation of protocatechuic acid in rat liver cytosolic preparations and cultured hepatocytes. Biol Pharm Bull. (2005) 28:1509-13. doi: 10.1248/bpb.28.1509

142. Kurogi M, Miyashita M, Emoto Y, Kubo Y, Saitoh O. Green tea polyphenol epigallocatechin gallate activates TRPA1 in an intestinal enteroendocrine cell line, STC-1. Chem Senses. (2012) 37:167-77. doi: 10.1093/chemse/bjr087

143. Kurogi M, Kawai Y, Nagatomo K, Tateyama M, Kubo Y, Saitoh O. Autooxidation products of epigallocatechin gallate activate TRPA1 and TRPV1 in sensory neurons. Chem Senses. (2015) 40:27-46. doi: 10.1093/chemse/bju057

144. Vriens J, Nilius B, Vennekens R. Herbal compounds and toxins modulating TRP channels. Curr Neuropharmacol. (2008) 6:79-96. doi: $10.2174 / 157015908783769644$

145. Akendengue B, Louis AM. Medicinal plants used by the Masango people in Gabon. J Ethnopharmacol. (1994) 41:193-200. doi: 10.1016/0378-8741(94)90032-9

146. Sugita J, Yoneshiro T, Hatano T, Aita S, Ikemoto T, Uchiwa H, et al. Grains of paradise (Aframomum melegueta) extract activates brown adipose tissue and increases whole-body energy expenditure in men. Br J Nutr. (2013) 110:733-8. doi: 10.1017/S0007114512005715

147. Sugita J, Yoneshiro T, Sugishima Y, Ikemoto T, Uchiwa H, Suzuki I, et al. Daily ingestion of grains of paradise (Aframomum melegueta) extract increases whole-body energy expenditure and decreases visceral fat in humans. J Nutr Sci Vitaminol. (2014) 60:22-7. doi: 10.3177/jnsv.60.22

148. Tajino K, Matsumura K, Kosada K, Shibakusa T, Inoue K, Fushiki T, et al. Application of menthol to the skin of whole trunk in mice induces autonomic and behavioral heat-gain responses. Am J Physiol Regul Integr Comp Physiol. (2007) 293:R2128-35. doi: 10.1152/ajpregu.00377.2007

149. Masamoto Y, Kawabata F, Fushiki T. Intragastric administration of TRPV1, TRPV3, TRPM8, and TRPA1 agonists modulates autonomic thermoregulation in different manners in mice. Biosci Biotechnol Biochem. (2009) 73:1021-7. doi: 10.1271/bbb.80796

150. Ma S, Yu H, Zhao Z, Luo Z, Chen J, Ni Y, et al. Activation of the cold-sensing TRPM8 channel triggers UCP1-dependent thermogenesis and prevents obesity. J Mol Cell Biol. (2012) 4:88-96. doi: 10.1093/jmcb/mjs001

151. Valente A, Carrillo AE, Tzatzarakis MN, Vakonaki E, Tsatsakis AM, Kenny GP, et al. The absorption and metabolism of a single L-menthol oral versus skin administration: Effects on thermogenesis and metabolic rate. Food Chem Toxicol. (2015) 86:262-73. doi: 10.1016/j.fct.2015.09.018

152. Tamura $\mathrm{Y}$, Iwasaki $\mathrm{Y}$, Narukawa $\mathrm{M}$, Watanabe $\mathrm{T}$. Ingestion of cinnamaldehyde, a TRPA1 agonist, reduces visceral fats in mice fed a high-fat and high-sucrose diet. J Nutr Sci Vitaminol. (2012) 58:9-13. doi: $10.3177 /$ jnsv. 58.9

153. Zuo J, Zhao D, Yu N, Fang X, Mu Q, Ma Y, et al. Cinnamaldehyde ameliorates iiet-Induced obesity in mice by inducing browning of white adipose tissue. Cell Physiol Biochem. (2017) 42:1514-25. doi: 10.1159/00047 9268

154. Giordano A, Frontini A, Cinti S. Convertible visceral fat as a therapeutic target to curb obesity. Nat Rev Drug Dis. (2016) 15:405-24. doi: $10.1038 /$ nrd.2016.31 
155. Villarroya F, Cereijo R, Villarroya J, Giralt M. Brown adipose tissue as a secretory organ. Nat Rev Endocrinol. (2017) 13:26-35. doi: $10.1038 /$ nrendo.2016.136

156. Kwon DY, Kim YS, Ryu SY, Cha MR, Yon GH, Yang HJ, et al. Capsiate improves glucose metabolism by improving insulin sensitivity better than capsaicin in diabetic rats. J Nutr Biochem. (2013) 24:1078-85. doi: 10.1016/j.jnutbio.2012.08.006

157. Okla M, Kim J, Koehler K, Chung S. Dietary factors promoting brown and beige fat development and thermogenesis. Adv Nutr. (2017) 8:473-83. doi: 10.3945/an.116.014332

158. Yoneshiro T, Matsushita M, Saito M. Translational aspects of brown fat activation by food-derived stimulants. Handb Exp Pharmacol. (2019) 251:359-79. doi: 10.1007/164_2018_159

159. Lorente-Cebrián S, Herrera K, Milagro FI, Sánchez J, Garza AL, Castro H. miRNAs and novel food compounds related to the browning process. Int $J$ Mol Sci. (2019) 20:5998. doi: 10.3390/ijms20235998
160

160.

Cypess AM, Haft CR, Laughlin MR, Hu HH. Brown fat
in humans: consensus points and experimental guidelines.
Cell Metab.
07.025

Conflict of Interest: The authors declare that the research was conducted in the absence of any commercial or financial relationships that could be construed as a potential conflict of interest.

Copyright $\odot 2020$ Saito, Matsushita, Yoneshiro and Okamatsu-Ogura. This is an open-access article distributed under the terms of the Creative Commons Attribution License (CC BY). The use, distribution or reproduction in other forums is permitted, provided the original author(s) and the copyright owner(s) are credited and that the original publication in this journal is cited, in accordance with accepted academic practice. No use, distribution or reproduction is permitted which does not comply with these terms. 